\title{
College English Teaching based on Mobile Learning
}

\author{
Zhang Lu \\ Shaanxi Polytechnic Institute, Xianyang, 712000, China \\ 47705926@qq.com
}

Keywords: mobile learning; college English teaching; vocabulary learning; listening learning; spoken learning; writing learning; reading learning

\begin{abstract}
The development of modern science and technology has provided technical support for the reform of college English teaching and has also brought opportunities and challenges to college English teaching. As a new learning mode, mobile learning expands the space-time and geographical boundaries of college English teaching and conforms to the requirements of the development of the times and College English teaching reform. In order to promote the application of mobile learning in college English teaching, this thesis, guided by the theory of constructivism, uses literature analysis, in-depth interviews and systematic analysis, combined with many years of teaching and research experience, from the perspectives of vocabulary learning, listening learning, Colloquial learning, writing learning and reading learning, and put forward the corresponding application strategies to guide the practice of college English teaching reform.
\end{abstract}

\section{Introduction}

Mobile learning relies on the maturity of wireless communications technology, wireless mobile networks and electronic information technology and other new electronic technologies, the main feature is the mobility [1]. The traditional teaching mode requires students to study in the classroom, and the mobile learning mode can be learned anytime, anywhere, without being limited by the objective environment. The mobile computing device used by mobile learning can effectively provide two-way interactive communication between teachers and learners. Without the limitation of time and space of the traditional teaching mode, improve the individuality and autonomy of student learning, it is an indispensable learning mode in the future, which opens up a new way for lifelong learning and education of all disciplines. College English is a compulsory course for college students. All colleges and universities should make full use of modern information technology to change the mode of "teacher-based" teaching. The new teaching mode should be based on network technology supplemented by the traditional teaching mode, the students' learning time and place is not restricted. The students' study mode is developed towards independence and personalization. The new college English teaching mode that combines mobile technology and traditional teaching mode is a necessary product of the new situation.

\section{Vocabulary Learning}

Vocabulary plays an important role in English learning. Wilkins states that "no grammar can only convey very little information, and nothing can be conveyed without a vocabulary." Students are at an advanced stage of English learning and have a basic grasp of grammar during college. Vocabulary learning is an important indicator of student progress. The College English Curriculum Requirements stipulate that 7675 words of "higher requirement" in college English should be given. The vocabulary number of high school graduates requires 3300. Well, 4375 need to master during the university, not only to grasp the conceptual meaning of words, but also must understand the relevance of the meaning. Common vocabulary learning includes three methods:

(1) English vocabulary learning based on short message. Teachers send text messages to students by flying letters, and students can receive new words anywhere. First, the teacher sends the word shape, pronunciation, and meaning of the new word; then, sends an example sentence or a short 
paragraph of text containing the new word; and finally, sends exercises and exercises based on the new word [2]. However, the amount of short message texts is small and can only serve as repeated words, remote reminder, and simply interact with each other. Multi-modal words cannot be presented.

(2) English vocabulary learning based on digital portable devices. Take advantage of digital portable devices with multimedia playback, including MP3 / MP4, players, smart phones, PDAs, and electronic dictionaries. This learning model, students' autonomy is strong. Teachers in the classroom to explain the content can be transmitted to the Internet, students download through the link campus, anytime, anywhere learning. Digital portable devices have large storage space, low price and easy popularization. Students can present learning content based on their learning ability and progress, or continue to read the word repeatedly to reduce the memory burden of words.

(3) APP-based English vocabulary learning. APP-based English vocabulary learning is an innovative learning method, taking full account of individual differences in students. Whether it is to enhance the number of English words, or understand the vocabulary collocation, are of great help [3]. Vocabulary learning has the characteristics of fragmentation. In order to attract students' attention, highlighting the characteristics of learning content and materials, learning in a limited time is not suitable for the wide coverage of content and the application of multiple learning techniques. Technical operation should not be too complicated. Suitable for the use of micro-learning, the use of small information units, relatively narrow topics, relatively simple problem plate, to build a simple and clear learning situation, to ensure learning efficiency and learning effectiveness.

\section{Listening Learning}

Listening is an important skill in language learning. To master listening is not only the purpose of learning English, but also an important means to improve one's own quality and expand foreign exchange. Therefore, in TOEFL, IELTS, English eight, College English CET exams, listening as a measure of English level is an important indicator. Most students' English listening and speaking lag behind the level of reading and writing, but also difficult to improve, this confusion has long plagued teachers and students in English. The traditional college English listening teaching adopts the form of "speaking, recording and answering". This teaching model only provides students with listening practice, seldom pays attention to students' listening comprehension, students' initiative and autonomy are not fully mobilized, but without any skill training. Therefore, in college English teaching, how to improve listening comprehension, to exclude hearing disorders, to master listening skills, and to improve students' listening comprehension has become one of the most important teaching and research topics.

Traditional English classroom teaching does not have a real language environment; there is not enough time for listening training. Smartphone with powerful multimedia capabilities and information processing capabilities, students use the smart phone through the Internet, and can enjoy and learn a variety of English-related audio and video, including English learning APP software, online listening to English audio of interest, Watch English online video, while entertaining also strengthened listening learning [4]. Students can download English songs, English movies, and other English audio and video using their smart phones, which can be played repeatedly to help students improve their English listening skills. The continuous improvement of smart phone functions, All kinds of mobile phone software emerge in endlessly, students use mobile phones to learn English listening process is no longer boring, but should be willing to experience and try. In the meantime, students contacted teachers through their cell phones to ask questions and expand the ways of communication between students and teachers. There are many materials for English Listening and Mobile Learning. Many students are confused in selecting materials. English teachers should provide assistance and recommend excellent materials to narrow the range of students' choices and improve students' listening learning efficiency [5]. 


\section{Spoken Learning}

In order to cope with various written test-based English exams, teachers teach more vocabulary and grammar knowledge, few students can use English to communicate fluently and "dumb" English have become the biggest obstacle to learning English. English as a language, the most basic function is to communicate and exchange, spoken learning is very important. But speaking has always been a difficult point in English learning. How to learn spoken English efficiently has become a hot topic that English educators and English learners pay close attention to. Due to the particularity and complexity of spoken language learning, the learning process is easily limited by learning situations, learning motivations, phonetic transcription and vocabulary syntax. The traditional method of learning spoken English, mainly through the classroom for a limited time to communicate, few students in English dialogue after class, the learners do not know whether the expression is correct. Using relevant English spoken learning software, students can choose their own learning goals, repeated follow-up training, and gradually improve their spoken communication skills [6].

At present, there are many APPs for spoken English learning, and the following four kinds of the most representative. Students can choose according to their needs: First, speak more English. Is a human-machine interaction practice spoken APP, has a wealth of practical scenarios courses, intelligent spoken language scoring system, imitation of conversational sentence recording for spoken practice, free foreign teachers counseling, easy practice anytime, anywhere, smart oral scoring system scored by verbatim sentence, witness the rapid increase in spoken language. Second, fluent in English. Spoken English learning that integrates innovative oral teaching concepts and cutting-edge speech assessment techniques. Pushed dialogue daily through systematic choreography, as long as the daily practice, can improve the level of English spoken. Starting from a real dialogue, the ability to promote vocabulary, grammar and listening is improved. Third, spoken English essence. Release "fresh, rich and interesting" learning content, while practicing English listening and speaking ability, broaden their horizons and broaden their knowledge, suitable for 15-35-year-old English learning enthusiasts to follow the daily learning, imitating the standard pronunciation, Improve English listening and speaking ability, subtly cultivate English thinking. Fourth, Akasuo speaking show. Featured American video clips made easy to learn video tutorials, while watching American films to practice speaking. Pure voice, soundtrack, and imitate the most pure voice. Follow imitation dialogue, dub for each sentence, and finally generate American film dialogue of their own dubbing.

\section{Writing Learning}

The level of writing is the embodiment of English comprehensive ability. Beginning with the analysis of English vocabulary, sentences, passages and texts, students can systematically master the basic knowledge of writing and basic skills through the practice of reading and writing of essay, and be proficient in writing various English applications essays to improve their writing ability, and strive to achieve accurate wording, correct grammar, in line with English habits. Through teaching students to lay a solid basic skill of written English expression, and training compound language talents. The current situation of college English writing teaching is not optimistic. Existing the following problems: the students' satisfaction with English writing teaching is low, their basic English skills are not solid, students' English language ability is poor, their writing is based on Chinese expressions, and the teaching mode of English writing is outdated. Mobile learning provides solutions for improving students' writing abilities, writing public numbers, writing mobile platforms, writing APPs and writing online open classes provide the basis for English mobile writing.

Another important aspect of writing for mobile learning is feedback. Writing feedback usually refers to the improvement of students' writing quality in English, writing tasks to complete the situation back to information. Feedback is an important part of writing teaching process. Effective feedback can balance learners' individual differences, satisfy learners' cognitive needs to the 
greatest extent, and directly affect learners' language acquisition and help learners improve their writing ability [7]. Each stage of writing requires feedback to help students complete writing cognitive constructs. The development of mobile communication technology and writing classroom gradually break the existing boundaries of time and space, and teachers and students, as well as students and students, have achieved extra-classroom interaction and realized the possibility of real-time, real-time and simultaneous feedback, creating students' independent writing learning opportunity. As the manager of online writing feedback, teachers should check the students' writing records in time and combined with electronic feedback records, feedback and help according to the students online practice data, so as to guide students to participate in more writing practice tasks and realize the benignity circulation of independent writing learning, to ensure the two-way interactive teaching. Students should fully understand their subjective consciousness in the whole writing feedback system. In addition to actively accepting feedback, students should boldly jump out of the role of long-term recipients of feedback, test their own language assumptions and promote their own writing skills.

\section{Reading Learning}

To improve students' English reading ability is not only the purpose of English study, but also a means of learning English well. It is also a way to test students' English knowledge, cultural knowledge, thinking ability and comprehensive ability to handle information. The famous scholar Mr. Ke Luke advocated a large number of reading as the main means of English teaching. Reading teaching should not only teach language knowledge, but also develop language skills. At present, under the background of less teaching hours, more content and heavy tasks, the effective way to improve students' skills of listening, speaking, reading, writing and translating is to increase the amount of reading, increase the amount of reading by contacting a large amount of language materials, Language intake, thereby enhancing the sense of language, expanding vocabulary, enriching the background knowledge, improve the flexibility of language use.

Mobile reading includes micro-blog, portable devices, APP and reading platform and many other ways [8], has the following advantages: first, the number of reading resources is huge. Traditional English reading is mainly through textbooks, and other paper books purchased by teachers and students are limited in quantity. Mobile Internet and cloud storage technology and the rapid development of mobile intelligent terminal equipment, students can access through the network English reading resources, but can also use paper reading materials to take pictures and so on, into suitable for mobile devices for electronic reading materials. Second, there are various types of reading resources. Mobile reading resources form, can be divided into pure text reading and multimedia reading, which is set to text, voice, video and picture for the integration of English reading resources; mobile reading themes, including politics, economy, education, sports and entertainment; From a genre point of view, English mobile reading also includes narrative, explanatory texts and essay and so on. Third, the speed of reading is faster. On the one hand, the rapid development of mobile Internet technology, user access network has entered the 4G era, access speed; on the other hand, students use the fragmented time for mobile reading, the basic content is fast browsing short. Fourth, the data generated by reading process is of great value. Analysis of students' reading content and reading behavior records, and can understand the students' reading interest, understand the students' reading habits and reading methods. At the same time, it provides an early warning mechanism for the development of students' English reading ability, and helps students develop good English reading habits.

\section{Application Countermeasures}

Mobile learning must motivate students' interest in learning and creativity by formulating appropriate countermeasures, so as to improve students' mobile learning ability and enable students to be in a positive and active learning state. The specific countermeasures are formulated in this paper as follows $[9,10]$ : 
(1) Teaching programs of design system. Before carrying out the mobile learning teaching, the teachers design the teaching plan systematically based on a full understanding of the students' English level, including the orientation of teaching objectives, the selection of teaching contents, the creation of teaching forms and situations, and the formulation of teaching evaluation standards. Teaching program is designed to highlight the characteristics of mobile learning teaching and classroom teaching, guiding students to use the correct mobile device to complete the learning task. The evaluation standards should be more user-friendly and personalized, to ensure that students make the correct assessment and objective evaluation.

(2)Play a guiding role of teachers. In mobile learning, teachers should ensure the correctness, completeness and timeliness of the English repository information. In the process of teaching implementation, should continue to interact with students through communication tools such as WeChat and QQ to guide students in learning, mastering and applying appropriate learning strategies to solve the problems encountered in the learning process. At the same time, in view of the phenomenon that Internet resources are too much and students are hard to choose, teachers should play a guiding role. Relying on teaching and learning experience, students should be guided to choose mobile learning materials suitable for their needs.

(3) Improve teaching content to adapt to mobile learning. Use the psychology of students who like modern information technology and Internet technology, to encourage students to learn English online using mobile communication devices and to acquire new knowledge anytime, anywhere using English learning software. Out of the tradition of teaching students, the English learning content will be extended to the classroom, so that students feel the Anglo-American culture, into the Anglo-American culture, really fell in love with English, passive learning as the active learning. Play multimedia features of mobile devices to experience the fun of mobile learning and enhance students' ability to express.

(4)Establish a diversified mobile learning model. English is an important communication tool, and learning and application environment have a significant impact on the learning effect. Building a diversified mobile learning model, and to integrate resources such as video, audio, text and animation, and to play advantage of video teaching, story teaching and situational teaching. The learning needs are combined with a specific learning phase to highlight the advantages of mobile devices. By strengthening cooperation of schools and software companies, teaching needs and resource design are combined to give full play to the advantages of mobile devices.

\section{References}

[1] R. Y. Pan, "Developing the Sustainable Ability of English Learning for College Students In the Mobile Learning Environment," Yinshan Academic Journal, vol. 27, no. 2, pp. 19-23, 2014.

[2] L. F. Yang, "The Application of Mobile Learning to College English Vocabulary Learning," Computer-Assisted Foreign Language Education, vol. 36, no. 2, pp. 54-58, 2012.

[3] L. L. Zhang, "APP design strategy for graduate English vocabulary based on mobile learning environment," Journal of Xingtai University, vol. 31, no. 4, pp. 134-137, 2016.

[4] X. Y. Yu, "Feasibility study of College English listening teaching based on mobile intelligent mobile learning model," Journal of Language and Literature Studies, vol. 35, no. 12, pp. 172-173, 2015.

[5] M. H. Li, G. M. Liu, "Application of mobile learning in College English listening teaching," Journal of Language and Literature Studies, vol. 34, no. 9, pp. 79-80, 2014.

[6] Y. Zhang, "Application of mobile learning in college spoken English learning," Western China Quality Education, vol. 3, no. 15, pp. 140-141, 2017.

[7] C. J. Hu, Y. C. Zhang, "A Study of College English Writing Feedback System Based on M-Learning," Modern Educational Technology, vol. 24, no. 7, pp. 71-78, 2014. 
[8] L. Y. Yuan, "Construction practice of College English reading based on mobile micro learning approach," Contemporary Education Research and Teaching Practice, vol. 4, no. 6, pp. 43-44, 2016.

[9] N. N. Li, "The application of mobile learning strategies based on smart phones in English Teaching," Journal of Wuhan Metallurgical Manager’s Institute, vol. 27, no. 1, pp. 77-79, 2017.

[10] J. Li, "On the Feasibility of College English Mobile Learning in West China: Taking Guangxi University as an example," Journal of Guilin Normal College, vol. 28, no. 1, pp. 129-132, 2014. 